\title{
"Measures are being taken to eliminate the consequences of the accident": Ideology and the Soviet Response to the Chornobyl Accident
}

\section{Angeles Espinaco-Virseda}

Although Soviet ideology has been identified as a factor leading to the Chomobyl disaster, there has previously been no discussion of its role in the official response to the accident or to its aftermath. Yet, as seen in the Soviet media, this muclear catastrophe triggered an ideological crisis which authorities stnuggled to respond to within a traditional dialectical framework. Paradoxically, their appeal to ideology in the management of this crisis contributed to growing disillusionment with the Soviet state and a reconsideration of Communism, leading, ultimately, to the collapse of the USSR.

Much has been said about the Chomobyl accident and its causes, and Soviet doctrine has often been a part of this discussion.! In that it has been suggested that ideology was a factor contributing to the Chornobyl disaster, it is appropriate to suggest that its involvement was also a factor in the Soviet reaction to the accident and its aftermath. ${ }^{2}$ In order to demonstrate the role of ideology in the response to this disaster and to show how it helped to bring about the collapse of communism in the Soviet Union, a brief discussion of Soviet scientific/technological and environmental theory will be followed by an analysis of their role in the official media response to the accident. In the aftermath of the disaster, efforts to explain the accident in ideological terms contributed, on the one hand, to the growing disillusionment with communism, and, on the other, for those who continued to follow the logic of its ideology, to demands for change in the Soviet system.

When Karl Marx described the evolution of economic

1 The author wishes to thank: Dr. David Mlaples for his kind suppont and for his translation of the Russian language sources ciled and Dr. David Duke for his patient guidance.

2 Paul R. Josephison. "The Historical Roos of the Chemobyl t)isaster." Sovicl Union I.3. no. I (1986). pp. 275-294; Paul R. Josephson. "Aloinic-Powered Communism: Nuclear Culture in the Muslwar USSR." Slonic Rrvirw' 55, no. 2 (Sunzere 1996). pp. 297-324: David Ibuke. "Soviet Conceptions of the Environinent" (1h. D. dist Univensity of Alberta, 1998). p. 226. 
history, he outlined a progression from savagery to communism. Running parallel to this evolution was the progression from the age of steam through to the age of electricity, and, by extension, the age of nuclear energy. ${ }^{3}$ The latler development was suggested as early as 1953 with the publication of From the Water Wheel to the Atomic Engine which helped to promote the idea that the Soviet Union was about to enter the stage of "communist construction." 4 This conviction was rooted in Marx's understanding of economic determinism which saw the development of productive forces as a fundamental indicator of the success or failure of society. Just as communism would be the ultimate stage of social evolution, nuclear energy represented the pinnacle of scientific and technological achievement. Thus, the implementation of a Soviet nuclear power program suggested that the dialectic of materialism, having already attained socialism, was ready to hegin the journey towards the social utopia of true communism. 5

Understood in this context, it is easy to see that Soviet 'gigantomania' (the penchant for large-scale and intensive building projects) was rooted in the cult of science and technology that emerged along with Stalin's drive to modernize. It also accounts for the urgency with which technological advancement, particularly the mass production of nuclear reactors, was pursued: the rapid production of nuclear power would speed the advance of social utopia. The importance of science to society was clear: if nuclear energy presented problems, the advanced state of science in socialist society would offer solutions. Similarly, the achievements of science would provide the tools necessary to further Soviet progress along the dialectical scale. ${ }^{6}$ In such a perfect society, concerns about the safety of nuclear power and the need to provide safety features on atomic reactors seemed both unnecessary and redundant. ${ }^{\text {? }}$

Once nuclear culture had been inserted into the ethos of technological utopianism, it promised to transform private and public life in the Soviet Union. Under the rubric of "the peaceful atom", the 3 Roundiable report. Itvestiya Vsesoyusnogo Grograficheskogo Obschelessva. No. 4 (1469), pp. $383-390$ cited in David Duke. "Sovict Conceptions of the Environumen" (Ph.D. diss.. Universily of Alberta, 19981. p. 209.

4 loseptison, "Alomic-Powered Comtrunism," p. 297.

5 lbid., pp. 297. 299.300.

6 Ibid. p. 298.

7 lbid. p. 299. 
effects of nuclear power extended from the irradiation of food (which in contrast to the United States was readily accepted in the Soviet Union) to the building of parks featuring nuclear reactors. ${ }^{8}$ So pervasive was the belief in science, that ordinary citizens wrote unsolicited letters to scientists suggesting new inventions.' Moreover, this scientism was in keeping with the regimes' emphasis on the scientific foundations of Marxism and served as a powerful counterpoint to the backwardness of the Tsarist regime and orthodox religion. ${ }^{10}$ Given the relatively rapid change of the Soviet Union from an illiterate and agrarian society into an educated, urban and industrial one, the evolution of a lechnological utopia through largescale production seemed attainable."

The Soviet culture of technology continued to flourish under Khruschev, who emphasized large-scale technology and personally promoted nuclear teclinology as a means by which to secure his own position in the struggle to succeed Stalin. Technological utopianism was a feature of Soviet regimes up 10 and including that of Brezhnev. It was idealized as "one of the highest forms of culture."12 Technological advancement engendered pride and prestige in the U.S.S.R. and was also seen as a means to challenge the superior position of the West. The spread of "Science to the Provinces" was a way of demonstrating at home and abroad that the republics were equal to the motherland in scientific culture. In Ukraine, nuclear culture was embraced by scientists and party officials with particular eagerness, ${ }^{13}$ suggesting their desire 10 be more than a Soviet 'satellite.' Thus, technology had a unique role to play in fulfilling political aims.

Notions of technological progress were also intertwined with the Socialist view of nature. ${ }^{1+}$ Although Marx himself had little to say on the subject, he did suggest that mankind would become progressively more alienated from the environment through the

8 bid., pp. 305-306, 308.

9 tbid. pp. 320.321.

10 bid., Joseptisan, "Hisionical Rocts," pp. 291.292.

II Joseplison, "Atomic.Powered Comtnunism." pp. 32.3.

12 Bsid. 297. 301: Joseptison. "Historical Roots," p. 293.

I.3 Jasephison. "Alomic-Powered Communism," pp. 313, 315. 
capitalist exploitation of nature. ${ }^{15}$ Once communism was achieved, this alienation would be reversed and there would be a renewed unity between humans and nature. In addition, Marx held that commodities obtained their value from human labour or exchange, implying that nature in its pristine state was without value. 16 Insofar as he gave little weight to the concept of scarcity as a source of value, there seems to have been an underlying assumption that natural resources were inexhaustible. ${ }^{17}$

Another source of Soviet views was Frederick Engels' Dialectic of Nature. Engels saw man, nature, and society locked in a three-way conflict. $18 \mathrm{He}$ believed, however, that science and communism would allow for man to progress, giving him the capability of making nature inexhaustibly productive. ${ }^{19}$

A basic element in the theories of both Marx and Engels was conflict. Human advancement through the dialectic of materialism necessitated revolution. Man's struggle against the social environment and nature entailed, at any one time, a conflict with one or the other, resulting in mastery. ${ }^{20}$ The consequence of these oppositional relationships was the overturning of earlier inferior orders, and the inevitable progress of humanity towards social utopia. (For this reason, the Soviet use of nuclear explosions for strip mining and other projects was seen as a means to "correct the many 'mistakes' of nature"). ${ }^{21}$ Essentially this presented a paradigm of opposing theses, that is, thesis and antithesis, in which the antithesis was defeated, and a new, superior thesis was inaugurated. ${ }^{22}$ Obviously, the struggle between socialism and capitalism and the resultant communism fell into this framework.

Soviet society, then, was guided by an ideological blend of antithetical struggles and utopian ideals. When the dialectics of materialism combined with these understandings of science, 14 Chartes Ziegler. "Soviet Eavirunmental Policy Paranneters: The Macro-value Framework," Studies in Sovies I5 Though 23, no. 3 (1982), p. 188.

16 Ibid. pp. 188-189.

17 bid.. pp. 189.100.

18 Ibid., p. 190: Scarcity would have addad value to a material which theoretically was equal to all other resources and which slabuld have hat no value wilhoul tuman labour. Hingels, Frederick. Dialectics of Natur (Mloscow: Foreign Languages Publishing Housc. 1954). pp. 237.245.

19 Ziegler. p. 191.

20 Bbid. p. I90.

21 Josephson. "Alomic.Powered Contununisın." p. 306.

22 David Iuke, "Soviet Science and the Envimnment" (keture given to llistery $\$ 19$ - The Envimnnxals History of the Soviet Union. 30 May 1999), Henry Manhal! Tory Building. Uaiversily of Athena. Finonton. 
technology, and nature, the result was Chornobyl. The role of ideology in bringing about the Chornobyl disaster has been examined by Paul R. Josephson. Josephson demonstrated that Soviet beliefs concerning the inherent safety of technology convinced them that they could mass produce large, sophisticated projects like nuclear reactors with few safety features and use non-technical personnel to operate them. ${ }^{23} \mathrm{He}$ further posited that the scientistic nature of Soviet Marxism, which saw science and technology as the key to economic development and the attainment of communism, merged with political and nationalistic aims, especially in the context of competition with the West. ${ }^{24}$ Together, these factors created the environment and the technical conditions for the accident.

A discussion of the official response to the Chornobyl disaster reveals the ongoing significance of ideology after the accident. The Sovict mass media played a particularly important role in shoring up the established system of beliefs. ${ }^{25}$ Indeed this role prompted a post-Chornobyl joke that the official news agency TASS was the best Soviet anti-radiation device in Eastern Europe. ${ }^{26}$ In general, it is obvious that "[T]here was a fear of extending glasnost to some very delicate and unacceptable questions one of which was Chernobyl."27

\section{On April 26, 1986 at 1:23 a.m., an experiment on the} Chornobyl atomic reactor No. 4 caused an explosion and a subsequent graphite fire. ${ }^{28}$ The immediate reaction by officials to the accident was one of confusion and perplexity. ${ }^{29}$ No public warnings were issued, and Swedish inquiries were met with official Soviet denials of an accident until April 28. At that time a government

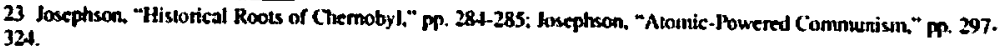

24 Joseptson. "Histarical Roots." pp. 289. 290-296.

25 Thomas F. Remingion, The Truth of Awhority: Ideology and Cononsonication in the Sowies Union (Piltshurgh: Universily of Piushught, 1988), pp. 97-107: Alla Yaroshinskaya, Chemobyl: The Forbidden Trush, trans. Michele Katn and Julia Sallatant: (Orford: In Capenter. 1944), pp. 125.127. 130.133: In addition, the fact that no article on Chornobyl appeas between 1986 and 1989 in the ideologically centred publication Intemational Affairs (Moscow) is indicative of the scrious challenge that the accident issued to the Sovief uould view.

26 IAszld Kunt, The Politics of loking: Popular Response to Chemobyl." Joumal of American Folkfore 101 (July/Septemher 1988), p. 333.

27 Iurii Shcherbak. Chemobyl: A Dorwhentary Siony. Imans. Ian Press, (Edmonton: Canadian Institute of Uhranian Studies, 1989l. p. 96. 
statement was made:

An accident has occurred at the Chernobyl Atomic Power Station; one of the nuclear reactors has been damaged. Measures are being taken to eliminate the consequences of the accident. Aid is being given to the victims. A government commission has been established. ${ }^{30}$

The wording of this first Soviet press release was revealing, especially the sentence "Measures are being taken to eliminate the consequences of the accident." Although the word "accident" does not have a positive connotation, in the context of Chornobyl it may be seen as a euphemism that significantly understated what might more accurately have been described as a disaster or catastrophe. It referred only vaguely to the immediate, localized cause of the atomic disaster, without acknowledging that the problems triggered by this "accident" (reactor meltdown and radioactive emissions) were out of control. More importantly, the use of the word "accident" shifted the emphasis away from technological failure toward human failure. Likewise, the phrase "measures are being taken to eliminate the consequences" was a powerful example of the way in which words could be manipulated to protect ideological beliefs. It avoided identifying the exact nature of the disaster, and simultaneously denied that the accident was ongoing or technological in nature. It also suggested that officials were in control of the situation.

The vague, euphemistic and only partially truthful nature of the statement had its origins in the fact that these events almost immediately challenged the Soviet world view: atomic energy, the infallible peak of Soviet scientific and technological achievement and the helpmate of socialism, had failed. Not only had it become unsafe,

28 David R. Maples, "Nuclear Power in the Fumer USSR: Historical and Contemporary Perspectives," in Nuctrar Energy and Security in the Fomuer Sovies Urion. eds. David R. Maples and Marilyn J. Young (Boukder. Colorado: Wesiview Press, 1997). p. 25.

29 David R. Marples. "The Chernobyl Disaster." Cument Mistony 86, no. 522 (1987): 325.328. 341-343: Stephen Oleskiw, "The Chomobyi Disaster. Causes and Consecpuences of the World's Worsl Nuclear Calastropte," The Utrainian Rniew 34. no. 4 (1986). p. 28

30 USSR Council of Miaisters. "Comntunique," IJrstia (30 April 1986). Trans. in The Current Digest of the Soviet Press |lyereinafler the CDSP) 18:16 (21 May 1986i. p.I. 
it had overthrown Soviet mastery. In addition, the "consequences of the accident," that is, severe radioactive environmental contamination, threatened to estrange Soviet citizens from nature. Clearly this contradicted both the harmonious union of man and nature anticipated in communist ideology, and the contention that capitalism alone alienated humans from the environment. That this disaster occurred within a socinlist state called into question the validity of Marx's predictions as well as the legitimacy of socialist thought. The ideological implications threatened to shatter the very foundations of the Soviet Union and, as a result, officials were unable to openly and clearly articulate what had occurred.

In trying to address the atomic crisis without identifying the true nature of the problem, the phrase "eliminating the consequences of the accident" became a mantra in Soviet discourse. News reports found in the Soviet press from April 1986 to April 1996 persisted in using this expression; ${ }^{31}$ sometimes it appeared more than once within the same article or paragraph. 32

The government's reluctance to deal directly with the full implications of the disaster was evident in the series of press releases that followed the April 26 explosion. A report that appeared on April 30 stated again that an accident had occurred, adding that part of the building and the reactor had been damaged and that there had been "some escape of radioactive substances." 33 This statement, along with others, continued the precedent of speaking only indirectly about the situation. In identifying the damage to the reactor and building, the report pointed to the localized accident rather than radioactivity as the primary problem. Similarly, the reference to radioactive emissions was vague and minimized. ${ }^{34}$ In fact, a formerly secret government protocol indicates that, by May 1, the government was using the media to document "normal activities" in contaminated regions. ${ }^{35}$ Other news reports in that early period

\footnotetext{
31 USSR Council of Ministers, "Conumunique," Jarstia (30 April 1986): "I Facts and Figures," Trud (25 April 1996). Trans in C1)SP 48:17 122 May 10961. p. 12.

32 V. Gubarev and M. Odinels, "The Siation and Around II," Pronvla (6 May 1986). Truns. in CDSP 18: 17 (28 May 199\$1. p. 3; Yury /hukov. "Involuntary Self.I:xposure." Prat da (6 May 1986) Trans. in (DSP 38:18 (4 June 1986). p.4.

33 USSR Council of Mtinisters. "Comununique." Prnyla (.W3 April 1986). Truns. in CDSP 38: 16 (21 May 1986). p. I.
} 
referred to the number of accident victims (two deaths); to the rumour circulating in the west of "thousands of deaths";," to the Chornobyl plant visit of CC CPSU Politburo members N. l. Ryzhkov and E. K. Ligachev; ${ }^{37}$ to the decline of radiation levels; and to decontamination. ${ }^{38}$ These points were made without reference to a nuclear meltdown, without conveying the nature of the injuries to the victims, the regions of contamination, the actual levels of radiation or the extent of the emissions. ${ }^{39}$ In providing information that did not reveal the true dimensions of the catastrophe, officials were able to avoid the ideological (and therefore, political) threat caused by the disaster.

Nevertheless, the world broadcast media potentially threatened to expose the truth. ${ }^{\text {to }}$ Simply protecting the ideology through controlled information was not sufficient, and a campaign of reindoctrination was begun, assisted by the spectacle of the traditional May Day parade, an event well-suited to bolstering patriotism and Soviet ideology. Despite the spread of radioactive contamination to Kiev, no warning or evacuation was issued and instead the parade was allowed to proceed. ${ }^{41}$ This was in spite the fact that May Day parades had been canceled in the past for such comparatively trifling reasons as rain. ${ }^{42}$ Indeed, the Polish Freedom and Peace Movement asserted that the parade was directed more carefully than ever before. ${ }^{43}$ The staging of the parade reinforced the ideological safety net because it celebrated socialist ideology with familiar slogans such as: "Workers in production, science and education! Increase your contribution to the acceleration of scientific and technical progress, to the fundamental reconstruction of the

\footnotetext{
34 kadiation kevels were said to he "inppoving" and water quality to be "in line with standards" IDavid R. Maptes, Chemobyl and Narlear Power in the USSR (Edmonton. All: Canadian Jnstitute of Uhrainian Studies, 1986). p. 7). 35 Yeroshinskaya, p. 131.

36 USSR Council of Ministers, OR Sovas Ministrov SSSR." Prunda (2 May 1986): "Poseshectenie majas

Chemobyl'shoy utomnoy stantsii." Prowkla (4 May 1986).

37 USSR Council of Ministers, "Ot Sowea Mlinistrov SSSR." Prunda (I May 1986)

38 Yaroshinskaya, p. 49.

39 A similar obser ation has been made abuut Boris leltsin's address to the Thinteenth Congress of the (ierman Connunist Party (KPD) on May 2, 1986. Marples, Chemubyl and Nurlear Power, pp. 8.9.

to Yurti Bohatiuk. "The Chomobyl Disister," The I/krainian Quarterly: A Joumbl of East Earopean und Asian Affairs 42 no. 1.2 (1986), pp. 8-10.

41 ibid. pp. 10-11.

42 Shchertak. Docuntentary. p. 94.

43 Kuzio, p. 26.
} 
national economy." +4

Calls to action such as this appeared to mitigate the damage (or potential damage) done by Chornobyl to the Soviet faith in science, technology and socialist progress. The parade offered officials the opportunity to reassert many of the Soviet ideals which had been undermined at Chornobyl. For instance, there were the usual slogans appealing directly to "Soviet scientists," "Machine builders" and to "workers in power engineering" called upon to "fulfill the Energy Program." 45 The broadly based and progressivist tenor of these and other slogans suggested Soviet superiority and mastery and the triumph of the Marxist dialectic.

In response to increased Western broadcasts such as Voice of America and Radio Liberty, ${ }^{46}$ the press shifted increasingly away from denials and veiled reports towards idealistic portrayals of a Soviet people mobilized to establish control. For example, a report on May 6 described at length "the courageous fellows," the firemen, who "significantly limited the extent of the accident." also detailed the heroic efforts of the Soviet people who acted together to overcome the situation and to "establish control over what was happening." 48 Workers offered their assistance by "volunteer[ing] their services, even though it was a Saturday,"49 drivers worked "tirelessly," including one who had "applied for Party membership,"s0 and "Kiev's doctors "responded solicitously to the misfortune'."51 Other Ukrainians took in the evacuees "with concern and heartfelt sympathy," and, as if suggesting the effectiveness of these mobilized socialists, livestock farmers were said to be "ahead of schedule in comparison with the same period of last year."52

44 CPSU Central Cominittec, "Slogans for May Day 1986," Pravia 113 April 1986). Trans in CDSP 38:15 (14 May 1986). p. 9.

45 CPSU Central Conumittex. "Slogans for May Day 1986."

46 Bohatiuk. 11; Guharev and Odinets. "Station and Anutnd lt." 2: This news repon. nuanking this change in strategy referted to "centain foreign wire services and all Linds of "radio voices" (that) tried to sow panic."

47 Couharev and Odinets, "Slation and Around": Maples, Chemolyl and Nurlear Peaner, p. I3.

48 A. Ulesh, "Situation Under Contml." Larstiu (7 May 1986). Trans, in (1)SP 38: 17 (28 May 1986). pp. 4, 22.23: Cuharev and Odinets, "Staition and Amund."

49 Maples. Chemolyyl and Nuclear Power. p. I4.

50 Gubarev and Odinets. "Station and Around."

SI Alarples, Chemotyl and Naciear Power. p. I4.

$\$ 2$ Gubarev and Odinets, "Siation and Around." 
Likewise, radio and newspapers announced repeatedly that everywhere worker's output was still at one hundred percent. ${ }^{53}$ In short, the media suggested that "order reigned." 54 This emphasis on the exemplary response to the crisis attempted to reinforce Soviet ideology by demonstrating the superior capabilities of the Socialist state and its people at the same time as it alluded to the imminent utopia.

The positive media emphasis continued for several days. 55 At the same time, however, a second strategy appeared to assimilate the Chornobyl accident into the structure of antithetical conflict. On May 3, Izvestia reported the running aground of an American nuclear submarine, which according to the article, was the second such incident for the United States in the past two months. ${ }^{56}$ What is remarkable about the story is that many aspects of it, both in content and phrasing, paralleled the reportage of the Chornobyl incident. For example, the phrase "a serious new incident has occurred on an American atomic submarine" seemed to echo the first public announcement of the Chornobyl accident: "An accident has occurred at the Chornobyl Atomic Power Station." 57 The article asserted that, not only had there been an American-caused nuclear incident, but that this was the second such incident in a short time and that the first had been kept a secret for a month. The report seemed intended to counter American criticisms of Soviet secrecy concerning the Chornobyl crisis, and to offset criticism of Chornobyl by pointing to persistent nuclear power problems in the America. ${ }^{58}$ By countering the Soviet accident with an American one, attention was deflected away from the disaster itself and refocused on the familiar East-West race to nuclear supremacy. ${ }^{59}$ Once again, thesis (the Soviet accident at Chernobyl) was set against antithesis (the American nuclear

\footnotetext{
53 Thomobyl in Polish Publications, The Utrainian Rniew 34, no. 4 (Winter 1986), p. 33.

S4 ciuharev and Odinets. "Starion and Around."

55 Illesh, "Situalion."

S6 "U.S.: The Allanta SufTers an Accident," Jarstia (3 May 1986). Trans. in CDSP 38: 18 (4 June 1986). p. I.

57 Ibid. USSR Council of Ministers. "Comunsiquse." Isrstia (30 April 1086)

58 "Ul raine Accidenl Veiled in Secrecy." Facts (On Filf 46. 120. 2.171 (2 May 1986), p. 305: Los Angeles Jnes. 2 May 1986.

59 Marples, Chernobyl and Nuctrar Power. p. 16.
} 
submarine accident) in a technological conflict that would result (according to Marxist belief) in the overthrow of the capitalist Americans and the continued upward progress of the superior socialist system. In this way, it was possible to incorporate the accident into a familiar ideological framework, reassert Soviet technical superiority, and continue to claim the dialectical advance of socialism over capitalism.

This oppositional relationship continued to be emphasized in other ways. The Soviet media decried "allempts by Western countries to use the accident for political ends." 60 It referred to "anti-Soviel" "ideological adversaries," "bourgeois propagand[ists],"61 "Western propagandists," 62 "anticommunis[ts]," and the "US state apparatus." 63 These references also alluded to the ideological conflicts that socialists had been taught that they were engaged in, and in so doing, reaffirmed established positions.

At the same time, the response of Soviet citizens, who compared the disaster with World War II, was consistent with the media portrayal of the accident as an antithetical conflict. Author lurii Shcherbak frequently made this comparison, but others, such as Anelia Perkovska, the secretary of the Prypiat Komsomol Town Committee, and author Vladimir Gubarev, did too. ${ }^{6+4}$ Certainly this association between the disaster and World War II was made because both required evacuation and both were highly traumatic events. However, it must also be noted that in the Soviet Union, World War II had been portrayed as an ideological war of communism against fascism. Thus the previous antithetical conflict served to indicate the occurrence of a new one.

The tendency to cast the event in terms of thesis/antithesis expanded to include the reactor itself. The press referred to the mounting of an "offensive" against the reactor and to the "first

60 lbid. p. 11.

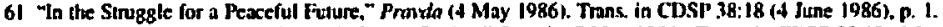

62 "On fivents at the Chernobyl Atomic Power Station," Pravila 77 May 1986). Trant. in CDSP 38: 18 (4 June 19861, p. 7.

6.3 Zhukov, "Involuntary": Additional cxamples of antithetical media neferences nay he faund in Maples.

Cherrobyl and Nuclear Power, pp. 18.19. 34

64 Shcherhal. Docemernary. pp. 61-62, 102.103, 159 
victory" over the fire. A river that was being diked in order to prevent the entry of contaminated run-off was said to have eventually "surrendered." 65 Medical personnel were described as operating in "combat conditions." 66 Even more revealing was a description of the struggle against the reactor under headline "Battle Without a Frontline." It featured the story of Major General Berdov, whose decorated military uniform was sacrificed as a result of contamination in the line of duty, and who kept a "combat operations journal."67 By implying that a war was being fought, the media implied that the Soviet people were engaged in a revolutionary battle that would, in the end, result in further progress towards communism and social utopia. In other words, the socialists were enacting a Marxist scenario: they would fight and overthrow the renegade reactor just as socialism struggled to overthrow capitalism. 68

While maintaining a largely positive attitude, Soviet news reports began to adopt a position that grudgingly conceded the accident at Chornobyl. Early approaches indicated the strain of accepting the failure of science. Nonetheless, they tried to portray the accident as a minor setback in an otherwise progressive ascent. For instance, one report from the USSR Ministry of Foreign Affairs Press Centre began by declaring: "The rapid progress of science and technology bring mankind not only benefits, for trailblazers' paths are always thorny [sic]. Neither the pole, space orbits, atomic energy nor the ocean depths are subdued without tragic losses."69 Chornobyl, this suggested, was only one of those "thorns," and like the natural world that the term evoked, it would be "subdued" and mastered by science which would continue to advance.

By approximately mid-May, as the extent of radioactive contamination became known, the scientific rhetoric intensified.

65 A. Iltesh. "Level of Tension," Isrstia (14 May 1986). Trans. in CUSP 38:20 (18 June 1986). p. 16. 66 Ibid

67 Vladimir Zhukovsky. Vladinir lthin and Lev Cluernenko, "Batle Wilurut a liront Iine." Sovetskaya Rossia (8 May 1986). Trans in CDSP 38:18 if lune 1986) p. II.

68 Or course this contraticied the notion of the perfection of technology. but the "battle strategy" singled out the neactor as an isolated villain. Notably. the reactor was briefly portrayed as a beast, which would also lave justified its subjugation; V. Gularev and M. Odinels, "Gorod, nxore i reahlor," Prenda (8 May 1986).

69 "On Events at lte Chamobyl Alontic Puwer Station." p. 5. 
Even though the European Community had banned all fresh food imports from the USSR and Eastern European nations, Soviet officials had announced the death of six people as a result of radiation exposure, and radioactivity from Chornobyl was detected over North America, Soviet officials continued to assert that science would solve the problems created by progress. ${ }^{70}$ The media offered highly optimistic accounts of decontamination procedures that used "special decontaminating film."7I In one report, containment of the radioactive fallout would utilize "an enormous stopper, composed of sand and other materials weighing in excess of 5,000 metric tonnes."72 Another stories described how the reactor would be contained by pouring "liquid glass" onto building roofs, by creating a "mighty cushion" filled with liquid nitrogen under the reactor, and by the construction of a "sarcophagus." detoxified. ${ }^{74}$ Despite the scale of the disaster, the media sought to reassure the public that the power of Soviet science would solve all problems, even those crealed by science itself.

However, the atomic accident did call into question the infallibility of atomic science and the presumed beneficial relationship between technology and Soviet man. In the words of V. A. Legasov, who led the delegation to the Vienna conference of the International Atomic Energy Agency, Chornobyl highlighted the "defects in the interactions of man and technology" where "machine and man should come to each other's aid when an accident occurs." In order to address this ideological crisis, blame was shifted from the reactor itself to the operators of the atomic plant, protecting the legitimacy of Soviet ideology and the Soviet state by assigning responsibility for the accident to human rather than to technical

70 Washington Post. II May 1986: Wadington Post, 13 May 1986.

71 lliesh. "Tension."

72 Mapples, Chemabyl and Nurlear Power. p. 12.

73 Jllesh. "Tension."

74 Bbid. As if to funther insis upen the reality of Soviet nuclear mastery. tearly all offers of thumanilarian and technical aid from the United States government volunteers and citizens were rebuffed with the aid provided by Dr. Robert Gale being the oaly exception (Willian H. Courtney, The Soviet Response to Chomobyl." The Utrainian Review ,4, no. 4 (Winter 1986). p. 36).

75 V. Guturev. "Through the Prism of Chernobyl," Pranda (5 Scptember 1986). Trans. in CDSP 38:38 (22 0ctoher 19861. p. 13. 
failure. $^{76}$

In the early days of the disaster, the damage to Soviet ideology was contained by the various media strategies discussed above. Although for some, disillusionment came early on with the realization that the "newspapers were writing lies," 77 many others remained unaware of the dangers that the government was hiding from them. ${ }^{78}$ Government propaganda tried to maintain the illusion that science and technology were infallible, that atomic energy was both the emblem and the means of socialist progress, that socialism was superior to capitalism, and that Soviet man was the master of all.

Yet, because of the nature and magnitude of the atomic accident, Soviet propaganda could not hide the health and environmental repercussions of the accident indefinitely. ${ }^{79}$ As the effects of the Chornobyl disaster became apparent, they elicited two different responses, both born of Soviet ideology. One was a sense of disillusionment, skepticism and anger arising from the apparent contradiction between the Soviet world view and reality. The other response involved the reconsideration and logical development of Soviet ideology in light of the disaster. In either case, the responses to the end of the Soviet state in its present form.

Ultimately "the consequences of the accident" led to ideological disillusionment because they called into question the fundamentals of Soviet thought regarding the relationship between man and nature. ${ }^{80}$ It had always been supposed that humans were separate from the natural world they mastered, but the indiscriminate physical effects of radiation made it all too clear that they were also

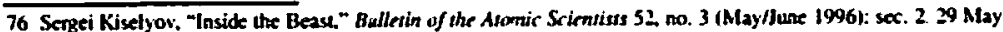
1999 shtp://www hallutomsci.org/issues/1996/mj96/mj96toc.html>

77 Shchestak. Doc umentory, pp. 69-71.

78 Bohativl, p. 11.

79 It apperas, though, Ihat propagandists did iry to hide them since by spring of 1987 . the press reports were being writen by the military mather than by journalists, and lie phrase "not for press" was increasingly invoked (David $R$. Marples. The Social Impart of the Chemobyl Disaster [tidmonton. AB: University of Altenta Press. 1988) p. 1301: V. A. Legasov; also of the I.V. Kunchatov Atonic Energy Institure stuted. "An accident has occurred that was considered improhahle. Therefore. lessons must be drawn from it - techrical, organizational and mychulogical kessons" (V. Gubares. "The Pain and Lessons of Chemobyl." Pratula [2 June 1986]. Trans. in CDSp 38:38 [22 October 1986). p. (3). This statement seems to have had particulas resonunce for Cuharev, since he incorporates it into fis play Sarrophegus, by having the chancter of the physicist say "And for thal we must study it (the accictent] from every aspact - Ihooretical, Ieclinical. psychobogical" (Vladimir Gubaryev, Sanrophtagus: A Tragedy. Irans. Mtichael Gilenny (New York: Vinuage Books. 1987). p. 72

80 Olestiw: pp. 6.17. 
a part of nature. The radioactive contamination of food, land, air and water made it clear that mankind was not just a part of nature, but also a subject of it. Furthermore, this new appreciation of the value of a pristine environment contradicted Marx's assertion that nature was valueless without labour. Ironically, this newly recognized dependence upon nature was nevertheless accompanied by alienation from the environment, something which was once believed to have only occurred under capitalism. In Belarus, Ukraine and Russia, Soviet citizens were effectively estranged from the parkland in a wide radius around the reactor site. ${ }^{81}$ In this way the extensive biological and environmental impact of Chornobyl pointed out the failings of Marx' and Engels' teachings and undermined the foundations of Soviet thought.

The ineffectiveness of Soviet medicine and the need for international aid in treating the radiation poisoning also challenged the supposed superiority of socialism over capitalism. Although the personal diplomacy of Armand Hammer (rather than governmental diplomacy) made the acceptance of American assistance palatable to Soviet officials, ${ }^{82}$ it was a disillusioning experience for the U.S.S.R. While Gorbachev thanked Hammer and Dr. Gale, an American physician, personally, ${ }^{83}$ the Soviets still tried to maintain the appearance of superiority. Dr. Angelina K. Gus'kova, the head of Moscow's Clinical Hospital No. 6, asserted that no country in the world could have managed such a catastrophe alone, and that Dr. Gale and his team merely complemented work begun by Soviet doctors. ${ }^{84}$ Regardless of these rationalizations, the acceptance of foreign medical assistance made it evident that the Soviet system was not capable of adequately dealing with the crisis, further calling into question the Marxist dialectic and its assertions concerning the superiority of the socialist system.

81 Manckorsky, "Kalastrofa: Chemu what uroki Chemobylya" Iaruia (26 March 1990).

82 Steve Weinherg. "Amand Hamuner"s Unique Diplonmacy." Bullelin of Wir Alomic Sriontists 42. no. 7

(AugusuSeptentber 1986. p. 50.

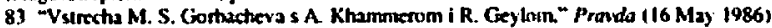

84 G Alimov and A. Illesh, 'Bol' Chemobylya: Interv' ya 'bestiy"." Iarstia (28 May 1986). 
Disillusionment with scientific dogmatism was also a consequence of the accident. One journalist hinted at it when he referred to Soviet radiation exposure guidelines as Lysenkoist. ${ }^{85}$ Writing four years after the disaster, when resettlement criteria were being developed that allowed levels of radiation exposure far in excess of those Western scientists considered acceptable, the author suggested that Soviet guidelines were at odds with the standards of the world scientific community, just as Lysenkoism once had been. ${ }^{86}$ In that Lysenkoism represented an extreme belief in the potential of Societ science, the comparison seemed intended to target the thinking that had caused and exacerbated the accident. In likening the government's policies to Lysenkoism, the journalist alluded to its dangerously unrealistic scientific utopianism and referred explicitly to the countless lives that Lysenkoism and Chornobyl had destroyed.

A similarly negative critique of Soviet science was evident in the play Sarcophagus, in which Vladimir Gubaryev portrayed a physicist's (over-)confidence in technology.87 In 1996 this negative assessment was reiterated by two surviving liquidation workers. One identified the Soviet belief in the infallibility of science and the pressure to quickly build atomic projects as the cause of the accident. 88 Another, a radiation monitor who was working at the station when it exploded, stated baldly: "Who is to blame for what happened? Soviet science and the Soviet system." Although he blamed Soviet science, he also saw careerism (which, it should be remembered, was fostered by a system that gave primacy to scientists in the socialist hierarchy) as responsible for the inadequate official response. ${ }^{89}$ The Chornobyl disaster forced Soviet society to confront and condemn scientific positivism.

85 A lemm laking its nane from the Soviet scientist Trofin Denisovich Lysenlo who opposed Mendelian genetics and $u$ two instead inajatrined the theory that acquired characteriscics are inherited by subsecpuent generations. Under Stalin. whose goal it was to create the New Sovict Mlan, Lysentio and his theory were given great sway over Soviet science as a whole. resulting in great damage to seientific reseanch as well as ruining the careets of geneticius and ohers. To refer to radiation guidelines as Lysenhoist, then, suggests that they are destructive. dangerously inealislic. and thove all, unscicntific

86 V. Bibikov, "Zone of Special Attention: We Have No Righu to Retreal," Sowriskaya Brbornssia (10 April 1990).

Trans. in COSP 62:1.3 (2 May 19902. p. 4 .

87 Miaples. Social Impract. p. 131; Gutaryev, Sarrophagus, pp. 55-56.

88 Kiselyor, sec. 2.

89 Ibid. sec. 3. 
Finally, popular disillusionment manifested itself in the appearance of the Green movement in Eastern Europe. In Moscow, after the accident, the Trust Group for Peace tried to organize a demonstration, but the activists were arrested en route. The protesters were, however, able to circulate a letter outlining their position. 90 People in Vilnius wrote to the Lithuanian Central Committee expressing concerns about future nuclear power plant projects in their country. Environmental and anti-nuclear groups also protested in Poland, Czechoslovakia, East Germany and Estonia."1 Popular concern over nuclear energy and the environment suggested a significant reversal of the public's unquestioning belief in science and the benefits of technological advancement. Once they had read journals, biographies and histories of science and scientists and offered suggestions for research and inventions, ${ }^{92}$ now they joined movements calling for a halt to the construction of new nuclcar reactors and demanding that existing stations be closed until they could be upgraded. ${ }^{93}$ The people turned the old slogans upside down, sarcastically declaring "A peaceful atom for every house!"14 The concerns raised by the Green movement went beyond the development and safety of nuclear technology. In Estonia, for example, where environmental concerns had already been unusually high prior to the accident, ecological problems were seen as being the product of Russian labour-intensive industries or 'gigantomania. 95

On the other hand, although it no longer pointed to the utopian end that Marx had envisioned, Soviet ideology could be modified to take into account new realities. For instance, Marxist theory suggested that natural resources were inexhaustible and inherently without value. After Chomobyl, the truth of this became ironically fulfilled. Nuclear energy, in the form of radioactive fallout, had multiplied itself to the extent that it was necessary to

90 Kizzio, p. 22.

91 tbid. pp. 23-25.

92 losephsca, -Atomic.Powered Contununism," pp. 320-322.

93 Kuzio, p. 22.

94 Kisclyov. p. 1.

95 Kuzio. p. 23. 
decontaminate forests, fields, buildings and people. ${ }^{96}$ It rendered useless, and therefore valueless, the natural resources which it contaminated. The staggering length of radioactive half-life heightened the awareness of atomic power's renewability; nuclear energy (and fallout) was not merely inexhaustible, ten years later it was called "eternal." 97 In Sarcophagus the only character to remain alive for the duration of the play is the one who received a heavy dose of radiation during the accident, and who was, paradoxically, named Immortal. Were he to die, his body would continue to be radioactive. In the case of nuclear energy, then, Marx's assertion about the infinite sustainability of natural resources had taken on a perverse new manifestation that was ironically fulfilled but not casily embraced.

The rhetoric of battle so often invoked at Chomobyl also elicited an ideological response to the disaster. If socialism was engaged in a struggle against an atomic reactor, that is, in a thesisantithesis conflict, then the question to be answered was, "What would be the new thesis?" For some, this implied a sinister new thesis with apocalyptic overtones: the word "Chornobyl" means "common wormwood" and the Revelation of St. John the Divine referred to "a star of Wormwood that falls to earth and causes people great unhappiness." 98 In other words, dialectical struggle had not resulted in progress; atomic energy was not the stepping-stone to a communist utopia. Instead, it had been revealed as harmful to the health of the people. The atomic age was not synonymous with progress or utopia. Scherbak identified this sentiment most succinctly when he stated that "the image of a new era, the atomic age,... is no longer a finesounding abstraction that we repeat lamely, but a harsh reality."99 As he observed after visiting Chornobyl: "I felt myself to be an astronaut who had returned to Earth from a distant and dangerous journey into

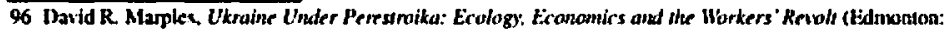
Univensity of Alberta Press, 19911. pp. 30-32

97 Arutré Hordyugovsky. "Prospect: likemal limitter of Dewh," Nezanisimaya gazera (15 May 1996). Trans. in CDSP 48:19 is June 1996h p. 10.

98 Yury Scherbah. "Report From Chumobyl: Withoul Conjectures or Innucndoes," Literutumaya gazela $(12$ July 1986). Trans. in CDSP 38:35 (1 October 1986). p. 12: Although this idea was said to lave heen pul forwand by Westem theologians, the fact that it was discussed in the Sorict press indicates a fairly broad level of Soniet popalas helief in this siory.
} 
the anti-world." 100 Ten years later, references 10 wormwood still appeared in the media, ${ }^{101}$ indicating the strength of the comparison. Rather than utopia, Chornobyl had inaugerated quite the opposite.

As Shcherbak has pointed out, following the disaster there were "catastrophists" but there were also "optimists."102 Some official sources continued to cling to a dialectical view of the revolution, which at least predicted an auspicious future into which the Soviet Union would lead the way. One article declared boldly that "Atomic power cannot be excluded from forward movement, from progress....Making the civilian atom safe and eliminating the mountains of nuclear weapons - these are tasks that must be solved for mankind to have a future." 103 Another declared:

Our country is prepared to participate constructively in its [the International Atomic Energy Agency's] work and considers the joint development of various states' scientists of a newgeneration reactor to be an urgent task. It is also necessary to spur on the cooperation in mastering controlled thermonuclear synthesis, which could become an inexhaustible energy source. 104

Such statements suggested a positive role for the Soviet people as leaders in the application of the peaceful atom, spreading communism, in part, by the continued development of those nuclear technologies which would lead towards utopin. Yet, in the antithetical model, progress towards a perfected social order entailed overturning the present Soviet state to make way for a new thesis.

As a product of Soviet ideology, the Chornobyl reactor was a symbol of the entire Soviet regime. Indeed, written on the roof edge

99 Yu. Schertak. "Worry and Jtope." Literitumaya gazeta (4 lune 1986). Trans, in CDSP 38:31 (3 Sept. 1986). p. 12.

100 Shehertak, Doxtomentan, p. 168.

101 Leonid Kapelyushny. "Ten Years with Chertobyl." Isvestia (25 April 1996). Trans. in CDSP $48: 19$ (5 June 14962. pp. 9.10; The joumalis Alla Yaroshinshaya alwo males this reference in the tille pages of her book Chemobyl: The Forbidden Truth mentioned previously.

102 Shchertak. Documeniany. p. 95.

103 B. Dubrovin and A. Pokrovsly. "Tale the Realities of the Nucleas Age Into Account, " Pmovia (26 Sept. 1986). Trans, in CDSP 38:39 129 Oct. 1986) p. 12.

104 th the Politburo of the CPSU Central Cotwnittec." Provklo (20 July 1936). Trans. in CDSP $38: 29$ (20 August 1986). P. 10. 
of reactor Unit 4 was the slogan "The Chernobyl Atomic Power Station, Bearing the name of V. I. Lenin, Labors for Communism!"'105 The reactor embodied the ideals of Soviet belief in scientific and technical progress and the superiority of Soviet man and atomic energy. Once the reactor exploded and wreaked destruction, it also became a symbol of the oppressive nature of that regime. The explosion had inflicted untold physical sufferings upon the Ukrainian and Belorussian people, had caused large scale evacuations, contaminated food sources, spoiled the environment and inflicted psychological terror. Likewise the Soviet regime had tortured and killed countless people, had moved workers to jobs according to the dictates of the state, had inflicted economic hardship and food scarcity, had despoiled the environment with factories and megaprojects and had used an atmosphere of intimidation to coerce the population. As a result, popular reactions to the disaster were linked to a larger backlash against the state. Near Chornobyl, peasants painted condemnatory slogans on the underground bunkers where party officials were reported to have hidden during the accident. They denounced these government officials as "Murderers of the Fatherland" and alluded to state gigantomania by calling them "Architects of Death." 106 In Poland, demonstrators overturned the entire East/West ideological dichotomy with placards that asked "Is an atomic death from the East any different?" 107 The Polish leader of a group named "Fighting Solidarity" called the USSR an "empire built upon lies," suggesting the general dishonesty of the government and disillusionment with the state's ideological foundation. ${ }^{108}$ In the past, the public had seen the "successes in space and nuclear research . . [as] proof positive of the legitimacy of the Soviet system." Now, the failure of Chornobyl called into question the validity of the Soviet system. ${ }^{109}$

In a similar way, Ukrainian writers reacted almost 
immediately to the accident with references to the Ukrainian famine (1932-1933), which had been caused by the Russians. They warned that yet another famine might result from the accident. ${ }^{\text {IO }}$ A press release by two former members of the Ukrainian Helsinki Group noted that "the tendency of the Soviet regime to suppress unpleasant events has cost the Ukrainian nation dearly in the past."II! More pointedly, in making the comparison to the famine, Yurii Bohatiuk referred to the "Kremlin's genocidal policy towards Ukrainians." 112 References to the famine were also made by Westerners. These and other comparisons had their basis in a number of similarities between the two events. 113 For example, large numbers of Ukrainian people were affected by the nuclear disaster and millions were killed by the famine. Many Ukrainians believed that "the Kremlin" had a longstanding hostility towards non-Russian nationalities. What they perceived as Russian indifference to Ukrainian loss of life during the famine was extended to Chornobyl. ${ }^{14}$ Furthermore, as during the famine, it seemed that the Soviet Union tried to isolate and contain both tragedies: in 1932-33, the Soviet authorities had sealed the Ukrainian borders; likewise the Chornobyl danger zone had initially been sealed off by special military and police units (mostly nonUkrainian, it was pointed out) and isolated when telephone and media access were cut. 115 This differential treatment was certainly alluded to in a joke that circulated at the time, suggesting that the way to $x$-ray a Muscovite was to put him between two Kyivites. Additionally, the high grain quotas of 1932-33, which seemed to deny the full scale of the famine, were comparable to the official denials. obfuscations and dangerously high contamination limits set by the government. Ukrainians in both the 1930s and the 1980s reacted to what they felt was their 'disposability' where Russian objectives such as Five Year Plans or the expansion of nuclear technology were

110 Oleskiw, p. 16

III Kurio. p. 21.

112 Jhohatiuk, pp. 12, 18, 21 .

113 Courtney, p. 36.

114 Bohatiuk, p. 20.

115 Oleshiw. pp. 13-14. 
concerned. Writers alluded to Russian gigantomania when they linked the disaster to Russian military needs which had resulted in hasty and reckless building projects. ${ }^{116}$ All of these similarities confirmed many Ukrainians in their belief that, in both the famine and at Chornobyl, Ukrainians had selectively been targeted for genocide by the Russians. Previously Ukraine had eagerly embraced nuclear culture as a great equalizer, after Chornobyl "Science to the provinces" was reinterpreted as "Genocide to the provinces."

The legitimacy of the state was also challenged by the presence of the Green Party, whose rise also seemed to herald a new order. In 1990, on the fourth anniversary of Chornobyl, the Green Party of Ukraine identified nuclear energy as an "undesirable industry" because it endangered the ecology, and because "its alleged administrative command structure" resembled that of the Brezhnev period. 117 The Greens' concerns about environmental destruction called into question the ideological foundation of the regime's policies and, in turn, undermined the legitimacy of the regime as a whole. ${ }^{118}$ This delegitimization was compounded by the emergence of the Greens as a political alternative to the once hegemonic Communist Party. In terms of their environmental concerns the Greens were the very antithesis of the Soviets. ${ }^{119}$ Moreover, they were founded as an attempt to be "anti-political" in that they resisted party hierarchies and strove for true participatory democracy. ${ }^{120}$ The rise of the Green Party was, then, a critique of the authoritarian regime that science and technology, epitomized by Chornobyl, had legitimized since the time of Stalin, and indicated the birth of a 'new politic.'

At the same time, the death of the old politic was played out at the reactor site. Ultimately, as the embodiment of Soviet abuses 
and ideology, the entombment of the disabled and dangerous Chornobyl reactor sent a powerful symbolic message that the practices and ideology of the old regime were also being buried. The construction of the 'sarcophagus' signaled the end of Soviet socialism.

Of course, to suggest that widespread disillusionment and the actual application of Soviet ideology to the disaster caused the dissolution of the Soviet Union implies that there was widespread belief in the Soviet ideology. While this subject can be debated at length, it should be noted that a deep rooted belief was not essential to an ideological interpretation of the disaster; only a familiarity with its discourse was. At least one popular joke suggested that the accident was seen by many people in these terms: "Why did the Chemobyl reactor blow up?" "Because the Hungarian uranium broke free from its enslavement."121

Those who believed in the socialist framework were led by the logic of their ideology to the outcomes suggested. Those who did not believe, but were raised in the Soviet system, would nonetheless have been able to use the ideological implications of the events to political advantage. ${ }^{122}$ Indeed, many political dissidents had learned to circumvent and manipulate Soviet ideology for their own causes. ${ }^{123}$

In conclusion, the Soviet need to respond to the Chornobyl disaster in ideological terms was a result of the challenges which the accident issued to the ideological foundations of the Soviet state. The values of science, technology, social utopianism, the dialectical supremacy of Soviet man, and man's relationship with nature were all put in doubt by the disaster. In order to preserve these beliefs and to protect the state. Soviet propaganda had to respond to these challenges. However, the process of assimilating this catastrophe

121 Kiani. p. 333.

122 There is perthaps. 2 thind calegory which should he nentioned: the simple people. thane whom scientific progress has passed by, but al the same time who suffered 'from our [Soviet] incompetency in scientific-technical progress" (Marples, Social Implac, 133). It may be suggested that their refusal to aceept the impact of Chomobyl their insistence upon retuming to ancestral tomes - placed them oxutside of the ideological ckhate.

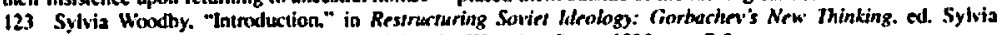
Woodby and Alfred B. Evans. Ir. (lloulder. Colorado: Wesview Press, 19901. pp. 7-8. 
into the traditional ideological framework produced new doubts and new understandings which portended the demise of the Soviet Union. On the one hand, the accident and its aftermath generated disillusionment with and an awareness of contradictions within ideology. On the other hand, the responses undertaken to preserve ideological understandings necessitated the institution of a new order. In effect, Soviet ideology had sown the seeds of its own demise, giving an ironic meaning to a phrase that was meant to give reassurance: "measures are being taken to eliminate the consequences of the accident." Indeed, the disaster had grave consequences for Soviet communism. 